Carla Slebodnick · James A. Ibers

\title{
Myoglobin models and steric origins of the discrimination between $\mathrm{O}_{2}$ and $\mathrm{CO}$
}

Received, accepted: 23 May 1997

\begin{abstract}
Synthetic models of the myoglobin active site have provided much insight into factors that affect $\mathrm{CO}$ and $\mathrm{O}_{2}$ binding in the proteins. "Capped" and "pocket" metal porphyrin systems have been developed to probe how steric factors affect ligand binding and ultimately to elucidate important aspects of the mechanism of $\mathrm{CO}$ discrimination in the proteins. These model porphyrins are among the most thoroughly characterized systems to date. From the twenty-one known crystal structures, analysis of the types of distortion that occur upon ligand binding under the cap, including porphyrin doming and ruffling, lateral and horizontal movement of the cap, and bending and tilting of the $\mathrm{Fe}-\mathrm{C}-\mathrm{O}$ bond, provides an indication of how steric interactions will affect structure in $\mathrm{Hb}$ and $\mathrm{Mb}$. The model porphyrin systems discussed range from those that discriminate against $\mathrm{O}_{2}$ binding compared to biological systems to those with similar $\mathrm{CO}$ and $\mathrm{O}_{2}$ binding strength to myoglobin, and also to those that bind both $\mathrm{O}_{2}$ and $\mathrm{CO}$ very weakly or not at all. The primary type of distortion observed upon $\mathrm{CO}$ binding is vertical or lateral movement of the cap and some ruffling of the porphyrin plane. Minimal bending or tilting of the $\mathrm{M}-\mathrm{C}-\mathrm{O}$ bond is observed, suggesting that the $\mathrm{Fe}-\mathrm{C}-\mathrm{O}$ bending that has been found from crystal structures of the hemoproteins is unlikely.
\end{abstract}

Key words X-ray structure · Biomimetic porphyrin · Iron · Ruthenium - Carbonyl

C. Slebodnick

Department of Chemistry, University of Michigan, Ann Arbor, MI 48109-1055, USA

\section{J. A. Ibers $(\varangle)$}

Department of Chemistry, Northwestern University, Evanston, IL 60208-3113, USA

Tel.: +1-847-491-5449; Fax.: +1-847-491-2976;

e-mail: ibers@chem.nwu.edu
Despite the fact that the oxygen-carrying hemoproteins hemoglobin $(\mathrm{Hb})$ and myoglobin $(\mathrm{Mb})$ are among the most studied of the proteins, the question of how structure affects $\mathrm{CO}$ and $\mathrm{O}_{2}$ binding to their heme centers remains contentious. These proteins contain a squareplanar heme [iron(II) protoporphyrin IX] that is embedded in the hydrophobic pocket of the globin; the heme and the globin are connected on the so-called proximal side by a covalent bond between the Fe center and a nitrogen atom of the imidazole group of a histidine residue. An open sixth coordination position on the distal side of the heme is the site of dioxygen binding. Other ligands, including $\mathrm{CO}, \mathrm{NO}$, and $\mathrm{RNC}$ bind at this site with respective affinities of approximately $10^{2}$, $10^{5}$, and $10^{-2}$ times those of $\mathrm{O}_{2}$ [1]. The binding of $\mathrm{CO}$ has been of particular interest because it is discriminated against: although $\mathrm{Hb}$ and $\mathrm{Mb}$ bind $\mathrm{CO}$ more strongly than $\mathrm{O}_{2}$, the $M$ value $\left[M=P_{1 / 2}\left(\mathrm{O}_{2}\right) / P_{1 / 2}(\mathrm{CO})\right]$ for $\mathrm{Hb}$ and $\mathrm{Mb}$ is much smaller than it is for unprotected model porphyrin systems [2, 3]. This discrimination, which in energy terms amounts to about $4 \mathrm{kcal} /$ mol, is vital, since $\mathrm{CO}$ is produced endogenously in various biological processes [2, 4], and approximately $3 \%$ of the heme sites in $\mathrm{Hb}$ are ligated by $\mathrm{CO}$, even with the discrimination [5].

A central question that has led to intense study of biological [6] and model systems [5, 7] is how this discrimination occurs. Is $\mathrm{O}_{2}$ binding stabilized or is $\mathrm{CO}$ binding destabilized in the biological systems? In fact, it is likely that both of these processes contribute to the lower value of $M$ by very different chemical means. Electronic interactions, including hydrogen bonding between the bound oxygen molecule and the proton of a distal histidine [8], are believed to stabilize the more polar $\mathrm{Fe}-\mathrm{O}_{2}$ bond [6]. Steric interactions are believed to destabilize $\mathrm{CO}$ binding. The cavity in heme proteins has evolved to accommodate $\mathrm{O}_{2}$ in its preferred bent geometry [9] but not $\mathrm{CO}$ in its preferred linear geometry [10]. As a result, for $\mathrm{CO}$ to bind at the iron center, distortion must occur through one or more energetically unfavorable processes, such as reorientation of the 
globin, ruffling or doming of the porphyrin plane, tilting of the $\mathrm{Fe}-\mathrm{C}-\mathrm{O}$ axis, or bending of the $\mathrm{Fe}-\mathrm{C}-\mathrm{O}$ bond. Because $\mathrm{O}_{2}$ is inherently bent, less distortion should be required to accommodate it. The structures of ligated $\mathrm{Hb}, \mathrm{Mb}$, and their mutants show considerable variability in porphyrin conformations and $\mathrm{Fe}-\mathrm{C}-\mathrm{O}$ and $\mathrm{Fe}-\mathrm{O}-\mathrm{O}$ angles $[6,11]$. Nevertheless, crystallographic results [12-15] show significant bending or tilting or both of the $\mathrm{Fe}-\mathrm{C}-\mathrm{O}$ linkage, despite the linearity of such a linkage in unencumbered systems. However, the precision of such results, and hence meaningful correlations of perceived trends with binding constants, is limited by the low resolution of protein crystallographic studies $[16,17]$. In fact, it is likely that errors in the Fe$\mathrm{C}-\mathrm{O}$ angle, when provided, are badly underestimated and could be as large as $25^{\circ}$ [16]. Thus the importance of steric factors in the discrimination against the binding of $\mathrm{CO}$ remains unknown.

Because of the general complexity of the globin and its interaction with the heme, model systems, for which high resolution crystal structures can be obtained, have been developed to probe how steric factors affect ligand binding and ultimately to elucidate important aspects of the mechanism of $\mathrm{CO}$ discrimination. Through the attachment of diverse organic protecting groups to the distal face of model porphyrins, the size, shape, and functionality of such systems can be systematically varied so that steric and electronic factors for $\mathrm{CO}$ discrimination can be addressed individually. A large variety of model compounds have been prepared, including "chelated" [18, 19], "strapped" [20-26], "picnic basket" [27], "picket fence" [28, 29], "pocket" [30-32] and "capped" [33-40] porphyrins as well as hybrids [41-43] of these different classifications.

Here we comment on the model systems classified as "pocket" and "capped" porphyrins that specifically address steric effects on ligand binding. Related studies of strapped porphyrin systems are available [43]. The steric barrier in the pocket and capped porphyrins is created by tethering a 1,3,5-substituted or a $1,2,4,5$-substituted benzene ring to the ortho positions of 5,10,15,20-tetraphenylporphyrin. The relevant capped and pocket porphyrins are sketched in Fig. 1. With these systems, the degree of steric protection incorpo- rated into the porphyrin is generally defined by the number of linkage atoms in the arms. For example, $\mathrm{H}_{2}\left(\mathrm{OC}_{2} \mathrm{OPor}\right)$, with an $-\mathrm{O}-\mathrm{CH}_{2}-\mathrm{CH}_{2}-\mathrm{O}-$ linkage, is referred to as a four-atom-linked capped porphyrin.

Pocket and capped porphyrins have been extensively characterized by single-crystal X-ray diffraction methods. Although it is difficult to make direct comparisons of $\mathrm{CO}$ and $\mathrm{O}_{2}$ binding constants for different systems because of the variety of conditions used in obtaining such data [7, 44], comparisons of general trends in binding constants with the structural changes that result from steric interactions upon ligation are useful in predicting the modes of steric discrimination in the ligation of $\mathrm{Hb}$ and $\mathrm{Mb}$. It is convenient to discuss the trends in $\mathrm{CO}$ and $\mathrm{O}_{2}$ binding in terms of two types of distal steric interactions defined in model systems: central (from directly above) and peripheral (from the sides) [45]. Central steric interactions should have a strong effect on the linear binding of $\mathrm{CO}$, whereas peripheral steric interactions should have little or no effect on $\mathrm{CO}$ binding but a strong effect on $\mathrm{O}_{2}$ binding. As the steric barrier becomes significant, types of distortions predicted in both proteins and model compounds include: (1) increased porphyrin ruffling or doming, (2) greater expansion of the distal protective group and, if there are central effects on $\mathrm{CO}$ binding, (3) tilting or bending of the $\mathrm{Fe}-\mathrm{C}-\mathrm{O}$ linkage or both.

These capped and pocket porphyrin Fe(II) model systems of Fig. 1 can be divided into four categories on the basis of their values of $P_{1 / 2}\left(\mathrm{O}_{2}\right), P_{1 / 2}(\mathrm{CO})$, and $M$ : (1) porphyrins for which no conclusions can be drawn regarding steric effects on ligand binding, (2) porphyrins that discriminate against $\mathrm{O}_{2}$ binding since they bind $\mathrm{O}_{2}$ with less affinity but $\mathrm{CO}$ with about the same affinity as $\mathrm{Hb}$ and $\mathrm{Mb}$, (3) porphyrins that show discrimination similar to $\mathrm{Hb}$ and $\mathrm{Mb}$, and (4) porphyrins for which $\mathrm{O}_{2}$ and $\mathrm{CO}$ affinities are significantly lower than in $\mathrm{Hb}$ and $\mathrm{Mb}$. We proceed to provide examples from these four categories.

The $\mathrm{C}_{4}$-Cap system is an example of Category 1 . Structural characterization of this system makes it clear

Fig. 1 Connectivity of capped and pocket porphyrins

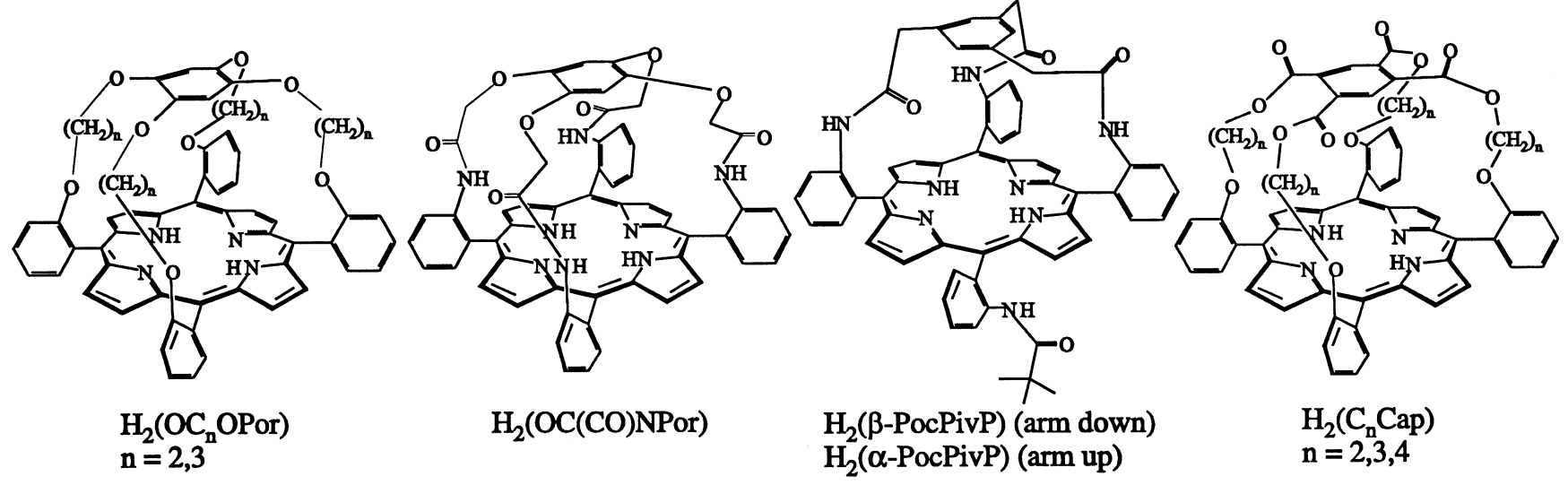


Table $1 \mathrm{O}_{2}$ and $\mathrm{CO}$ binding to $\mathrm{Fe}^{\mathrm{II}}$ porphyrin complexes and hemoproteins ${ }^{\mathrm{a}}$

\begin{tabular}{|c|c|c|c|c|}
\hline & $P_{1 / 2}\left(\mathrm{O}_{2}\right)$ (Torr) & $P_{1 / 2}(\mathrm{CO})($ Torr $)$ & $M=P_{1 / 2}\left(\mathrm{O}_{2}\right) / P_{1 / 2}(\mathrm{CO})$ & Reference \\
\hline $\begin{array}{l}\mathrm{Mb}(\text { elephant) } \\
\mathrm{Mb} \text { (horse) }^{\mathrm{b}}\end{array}$ & $\begin{array}{l}0.62 \\
0.70\end{array}$ & $\begin{array}{l}9.5 \times 10^{-2} \\
1.8 \times 10^{-2}\end{array}$ & $\begin{array}{l}6.5 \\
39\end{array}$ & $\begin{array}{r}56 \\
1\end{array}$ \\
\hline \multicolumn{5}{|l|}{ R-state systems } \\
\hline $\begin{array}{l}\mathrm{HbA}(\mathrm{R})^{\mathrm{b}} \\
\mathrm{Fe}(\mathrm{PocPivP})(1-\mathrm{MeIm}) \\
\mathrm{Fe}\left(\mathrm{OC}_{2} \mathrm{OPor}\right)(1-\mathrm{MeIm}) \\
\mathrm{Fe}(\mathrm{OC}(\mathrm{CO}) \text { NPor }) \\
\mathrm{Fe}\left(\mathrm{C}_{2} \text {-Cap }\right)(1-\mathrm{MeIm}) \\
\mathrm{Fe}\left(\mathrm{C}_{2} \text {-Cap }\right)(1,5-\mathrm{DCIm}) \\
\mathrm{Fe}\left(\mathrm{C}_{3} \text {-Cap }\right)(1,5-\mathrm{DCIm}) \\
\mathrm{Fe}\left(\mathrm{C}_{4} \text {-Cap }\right)(1,5-\mathrm{DCIm})\end{array}$ & $\begin{array}{l}\quad 0.22(\alpha)^{\mathrm{d}}, 0.36(\beta)^{\mathrm{d}} \\
0.36 \\
61^{\mathrm{f}} \\
>7.7 \times 10^{4} \\
23,4.5^{\mathrm{c}} \\
- \\
54^{\mathrm{c}} \\
-\end{array}$ & $\begin{array}{l}1.4 \times 10^{-3 \mathrm{~d}} \\
1.5 \times 10^{-3} \\
100,40^{\mathrm{c}}, 17^{\mathrm{g}} \\
>7.7 \times 10^{4} \\
5.4 \times 10^{-3} \\
7.5 \times 10^{-3} \\
4.1 \times 10^{-3} \\
0.21\end{array}$ & $\begin{array}{l}160(\alpha), 260(\beta) \\
240 \\
- \\
- \\
4300 \\
- \\
- \\
-\end{array}$ & $\begin{array}{l}30,57-60 \\
30 \\
54 \\
54 \\
61,62 \\
35 \\
62 \\
35\end{array}$ \\
\hline \multicolumn{5}{|l|}{ T-state systems } \\
\hline $\begin{array}{l}\mathrm{HbA}(\mathrm{T})^{\mathrm{b}} \\
\mathrm{Fe}(\mathrm{PocPivP})\left(1,2-\mathrm{Me}_{2} \mathrm{Im}\right) \\
\mathrm{Fe}\left(\mathrm{OC}_{2} \mathrm{OPor}\right)\left(1,2-\mathrm{Me}_{2} \mathrm{Im}\right) \\
\mathrm{Fe}\left(\mathrm{C}_{2}-\mathrm{Cap}\right)\left(1,2-\mathrm{Me}_{2} \mathrm{Im}\right) \\
\mathrm{Fe}\left(\mathrm{C}_{3}-\mathrm{Cap}\right)\left(1,2-\mathrm{Me}_{2} \mathrm{Im}\right) \\
\mathrm{Fe}\left(\mathrm{C}_{4}-\mathrm{Cap}\right)\left(1,2-\mathrm{Me}_{2} \mathrm{Im}\right)\end{array}$ & $\begin{array}{l}\quad 40(\alpha)^{\mathrm{d}}, 140(\beta)^{\mathrm{d}} \\
12.6 \\
>760 \\
4000 \\
-\quad 880^{\mathrm{e}}\end{array}$ & $\begin{array}{c}0.3^{\mathrm{d}} \\
6.7 \times 10^{-2} \\
\sim 5000 \\
0.2 \\
0.14 \\
4.1\end{array}$ & $\begin{array}{l}130(\alpha), 470(\alpha) \\
220 \\
- \\
\quad 2.0 \times 10^{4} \\
-\end{array}$ & $\begin{array}{l}30,59,60,63 \\
30 \\
54 \\
61,62 \\
64 \\
35\end{array}$ \\
\hline $\begin{array}{l}{ }^{a} \text { Measurements were made } \\
\text { noted } \\
\text { b }{ }^{\mathrm{C}} \mathrm{H}_{2} \mathrm{O}, \mathrm{pH} \sim 7 \\
{ }^{\mathrm{c}} 0^{\circ} \mathrm{C}\end{array}$ & ene at $25^{\circ} \mathrm{C}$ unless oth & $\begin{array}{l}\text { d } 20^{\circ} \mathrm{C} \\
\text { e }-63^{\circ} \mathrm{C} \\
\text { f }-43^{\circ} \mathrm{C} \\
\text { g }-20^{\circ} \mathrm{C}\end{array}$ & & \\
\hline
\end{tabular}

that solvents get trapped under the cap [46]. This seven-atom-linked capped porphyrin system is conceivably of use as a model for solvent displacement, such as a water in hemoglobin, but it is not of use as a probe of steric effects.

The $\mathrm{C}_{3}$-Cap, $\mathrm{C}_{2}$-Cap, and $\mathrm{OC}_{3} \mathrm{OPor}$ systems are examples of Category 2 (models that discriminate against $\mathrm{O}_{2}$ binding). In these systems, the $P_{1 / 2}(\mathrm{CO})$ value is within an order of magnitude of that reported for $\mathrm{Hb}$, whereas the $P_{1 / 2}\left(\mathrm{O}_{2}\right)$ value is approximately two orders of magnitude greater than for $\mathrm{Hb}$ (Table 1). Presumably, peripheral steric effects are stronger here than in the proteins, but the central steric effects are about the same [47]. The four five-atom or six-atom linkages connecting the benzene cap to the porphyrin can readily expand vertically to accommodate a linear CO ligand, but such arms severely impair horizontal movement of the cap. Additional energy is required to accomplish such movement, which is needed to accommodate the bent $\mathrm{Fe}-\mathrm{O}-\mathrm{O}$ linkage, and a higher value of $P_{1 / 2}\left(\mathrm{O}_{2}\right)$ results. Comparison of the structure of the free base, $\mathrm{H}_{2}\left(\mathrm{C}_{3}\right.$-Cap), with that of the carbonyl, $\mathrm{Fe}\left(\mathrm{C}_{3}\right.$-Cap) (CO)(1-MeIm), indicates that the vertical flexibility is available: the cap expands $2.3 \AA$, from $\sim 3.5 \AA$ to $\sim 5.9 \AA$, upon CO ligation [46]. Similarly, $\mathrm{C}_{2}$-Cap expands $\sim 1.6 \AA$ and $\mathrm{OC}_{3} \mathrm{OPor}$ expands $\sim 0.9 \AA$, to $\sim 5.6 \AA$, upon CO ligation (Table 2) [47-49]. In all three systems, lateral movement of the cap and distortion of the porphyrin plane are minimal, and the $\mathrm{Fe}-\mathrm{C}-\mathrm{O}$ bond remain essentially linear and untilted.

The PocPivP system, for which the $\mathrm{O}_{2}$ and $\mathrm{CO}$ affinities are close to those for $\mathrm{Hb}$ and $\mathrm{Mb}$ (Table 1), is an example of Category 3. From a comparison of the structure of $\mathrm{H}_{2}(\alpha$-PocPivP) [46] with those of $\mathrm{Ru}(\beta$ PocPivP $)\left(\mathrm{H}_{2} \mathrm{O}\right)_{\text {in }}(\mathrm{CO})_{\text {out }}$ [50], Ru( $\alpha$-PocPivP $)(\mathrm{CO})(1-$ MeIm) [51], and Fe( $\beta$-PocPivP $)(\mathrm{CO})\left(1,2-\mathrm{Me}_{2} \mathrm{Im}\right)$ [52], it is apparent that horizontal displacement of the cap is the main type of distortion that occurs when $\mathrm{CO}$ or $\mathrm{H}_{2} \mathrm{O}$ binds under the cap (Table 2). The cap moves laterally as much as $1.44 \AA$, from $1.86 \AA$ in $\mathrm{H}_{2}(\alpha$-PocPivP) to $3.30 \AA$ in $\mathrm{Fe}(\beta$-PocPivP $)(\mathrm{CO})\left(1,2-\mathrm{Me}_{2} \mathrm{Im}\right)$. The three-atom arms of the pocket porphyrin severely limit vertical expansion of the cap, but the lack of a fourth arm allows the cap to move sideways to minimize steric interactions. Steric strain may also cause increased distortion of the porphyrin plane, but this also appears to be a function of whether the pivalamido arm is oriented up $(\alpha)$ or down $(\beta)$ and may simply be a manifestation of crystal packing effects.

The four-atom-linked porphyrins $\mathrm{OC}_{2} \mathrm{OPor}$ and $\mathrm{OC}(\mathrm{CO})$ NPor $[38,53]$, the most sterically encumbered porphyrins reported to date, are examples of Category 4 (systems that show $\mathrm{CO}$ and $\mathrm{O}_{2}$ affinities significantly lower than do $\mathrm{Hb}$ and $\mathrm{Mb}$ ). $\mathrm{O}_{2}$ and $\mathrm{CO}$ binding studies with these capped porphyrins indicate that steric factors do affect $\mathrm{CO}$ binding: the $\mathrm{OC}_{2}$ OPor system has one of the highest $P_{1 / 2}(\mathrm{CO})$ values, 100 Torr at $25^{\circ} \mathrm{C}$ [54] measured to date for any system, biological or model, although there is one example of a system that does not bind $\mathrm{CO}$ at 760 Torr [40], and OC(CO)NPor does not bind $\mathrm{CO}$ or $\mathrm{O}_{2}$ even at a pressure of $7.6 \times 10^{4}$ Torr [54]. Because these values of $P_{1 / 2}(\mathrm{CO})$ are so much higher than those for $\mathrm{Hb}$ and $\mathrm{Mb}$, we conclude that steric effects on ligation of $\mathrm{Hb}$ and $\mathrm{Mb}$ are small compared with such effects in these models. Therefore, if $\mathrm{CO}$ does not bend or tilt in the $\mathrm{OC}_{2} \mathrm{OPor}$ 
Table 2 Porphyrin distortions

\begin{tabular}{|c|c|c|c|c|c|}
\hline Structure & $\begin{array}{l}\text { Average deviation } \\
\text { from } 24 \text {-atom } \\
\text { plane }(\AA)\end{array}$ & $\begin{array}{l}\text { Vertical } \\
\text { displacement } \\
\text { of cap }(\AA)^{\mathrm{a}}\end{array}$ & $\begin{array}{l}\text { Lateral } \\
\text { displacement } \\
\text { of cap }(\AA)^{\mathrm{b}}\end{array}$ & $<\mathrm{M}-\mathrm{C}-\mathrm{O}$ & Reference \\
\hline $\mathrm{H}_{2}(\alpha$-PocPivP $)$ & 0.10 & 4.21 & 1.86 & - & 46 \\
\hline $\operatorname{Ru}(\beta$-PocPivP $)\left(\mathrm{H}_{2} \mathrm{O}\right)_{\text {in }}(\mathrm{CO})_{\text {out }}$ & 0.21 & 4.23 & 3.01 & $178.7(3)$ & 50 \\
\hline \multirow{2}{*}{$\operatorname{Ru}(\alpha$-PocPivP $)(\mathrm{CO})(1-\mathrm{MeIm})$} & 0.13 & 4.39 & 2.82 & $168(3)$ & \multirow{2}{*}{51} \\
\hline & 0.15 & 4.37 & 2.74 & $159(3)$ & \\
\hline $\mathrm{Fe}(\beta-\mathrm{PocPivP})(\mathrm{CO})\left(1,2-\mathrm{Me}_{2} \mathrm{Im}\right)$ & 0.27 & 4.25 & 3.30 & $172.5(6)$ & 52 \\
\hline $\mathrm{H}_{2}\left(\mathrm{OC}_{2} \mathrm{OPor}\right)$ & 0.10 & 3.81 & 0.54 & - & 38 \\
\hline$\left[\mathrm{Fe}\left(\mathrm{OC}_{2} \mathrm{OPor}\right)\right]_{2}(\mu-\mathrm{O})$ & 0.05 & 3.46 & 0 & - & 53 \\
\hline $\mathrm{Fe}\left(\mathrm{OC}_{2} \mathrm{OPor}\right)(\mathrm{OMe})$ & 0.07 & 3.93 & 0.54 & - & 53 \\
\hline $\mathrm{Ru}\left(\mathrm{OC}_{2} \mathrm{OPor}\right)\left(\mathrm{H}_{2} \mathrm{O}\right)_{\text {in }}(\mathrm{CO})_{\text {out }}$ & 0.06 & 4.80 & 0.60 & 178.1(4) & 50 \\
\hline $\mathrm{H}_{2}[\mathrm{OC}(\mathrm{CO}) \mathrm{NPor}]$ & 0.06 & 3.90 & 1.10 & - & 38 \\
\hline $\left.\mathrm{H}_{2} \mathrm{OC}_{3} \mathrm{OPor}\right)$ & 0.07 & 4.74 & 0.54 & - & 49 \\
\hline $\mathrm{Fe}\left(\mathrm{OC}_{3} \mathrm{OPor}\right)(\mathrm{CI})$ & 0.15 & 4.65 & 1.35 & - & 49 \\
\hline $\mathrm{Fe}\left(\mathrm{OC}_{3} \mathrm{OPor}\right)(\mathrm{CO})(1-\mathrm{MeIm})$ & 0.08 & 5.55 & 0.21 & $173.9(7)$ & 49 \\
\hline $\mathrm{Fe}\left(\mathrm{OC}_{3} \mathrm{OPor}\right)(\mathrm{CO})\left(1,2-\mathrm{Me}_{2} \mathrm{Im}\right)$ & 0.07 & 5.59 & 0.66 & $180.0^{\mathrm{c}}$ & 49 \\
\hline $\mathrm{H}_{2}\left(\mathrm{C}_{2}\right.$-Cap $)$ & 0.13 & 3.96 & 0.12 & - & 48 \\
\hline $\mathrm{Fe}\left(\mathrm{C}_{2}-\mathrm{Cap}\right)(\mathrm{Cl})$ & 0.08 & 4.01 & 0.24 & - & 65 \\
\hline \multirow{2}{*}{$\mathrm{Fe}\left(\mathrm{C}_{2}\right.$-Cap)(CO)(1-MeIm) } & 0.08 & 5.57 & 0.30 & $172.9(6)$ & \multirow[t]{2}{*}{47} \\
\hline & 0.08 & 5.67 & 0.00 & $175.9(6)$ & \\
\hline $\mathrm{H}_{2}\left(\mathrm{C}_{3}-\mathrm{Cap}\right)$ & 0.27 & 3.49 & 0.20 & - & 46 \\
\hline $\mathrm{Co}\left(\mathrm{C}_{3}-\mathrm{Cap}\right)$ & 0.31 & 3.50 & 0.20 & - & 66 \\
\hline $\mathrm{Fe}\left(\mathrm{C}_{3}-\mathrm{Cap}\right)(\mathrm{CO})(1-\mathrm{MeIm})$ & 0.04 & 5.86 & 1.03 & $178.0(13)$ & 46 \\
\hline $\mathrm{H}_{2}\left(\mathrm{C}_{4}-\mathrm{Cap}\right)$ & 0.08 & 7.28 & 0.69 & - & 46 \\
\hline \multirow[t]{2}{*}{$\mathrm{Fe}\left(\mathrm{C}_{4}-\mathrm{Cap}\right)(\mathrm{Cl})$} & 0.04 & 7.12 & 0.40 & - & \multirow[t]{2}{*}{46} \\
\hline & 0.07 & 7.66 & 0.52 & - & \\
\hline
\end{tabular}

${ }^{a}$ The vertical displacement of the cap is the perpendicular distance of the cap centroid from the mean 24-atom porphyrin plane

${ }^{b}$ The lateral displacement of the cap is defined as the distance of the cap centroid from the above perpendicular

${ }^{\mathrm{c}}$ By symmetry

system, it probably is not bent in $\mathrm{Hb}$ or $\mathrm{Mb}$. What is the structural basis for the steric discrimination against $\mathrm{CO}$ binding in these four-atom-linked capped porphyrins? Unfortunately, the structure of $\mathrm{Fe}\left(\mathrm{OC}_{2} \mathrm{OPor}\right)(\mathrm{CO})$ (base) is not known. In the structure of $\mathrm{Ru}\left(\mathrm{OC}_{2} \mathrm{OPor}\right)\left(\mathrm{H}_{2} \mathrm{O}\right)_{\text {in }}(\mathrm{CO})_{\text {out }}$ [50], the cap centroid lies $4.8 \AA$ above the porphyrin plane. From the three carbonyl structures reported for five-atom-linked capped porphyrin systems, which all have a cap-to-porphyrin distance of $\sim 5.6 \AA$, it appears that the cap in $\mathrm{OC}_{2} \mathrm{OPor}$ must expand an additional $0.8 \AA$ to accommodate a linear Fe-C-O linkage. Preliminary EXAFS results [H.C. Freeman, D. Shi, P.J. Ellis, B. Hedman, K.O. Hodgson, C. Slebodnick, J.A. Ibers, unpublished results] on $\mathrm{Fe}\left(\mathrm{OC}_{2} \mathrm{OPor}\right)(\mathrm{CO})(1-\mathrm{MeIm})$ are consistent with a linear $\mathrm{Fe}-\mathrm{C}-\mathrm{O}$ linkage. Hence structural reorientation must occur through distortion of the cap and porphyrin. To bind $\mathrm{CO}$ or $\mathrm{O}_{2}$ to $\mathrm{Fe}(\mathrm{OC}(\mathrm{CO})$ NPor $)$ would require vertical expansion of the cap with concomitant non-planarity of the amide groups in each arm. This process is so energetically unfavorable as to preclude such binding, even at very high pressures.

In summary, with the exception of one structure $[\mathrm{Ru}(\alpha$-PocPivP $)(\mathrm{CO})(1-\mathrm{MeIm})]$ of relatively poor quality, where the two independent $\mathrm{Ru}-\mathrm{C}-\mathrm{O}$ angles are $159(3)^{\circ}$ and $168(3)^{\circ}$ (Table 2) [51], structural data for the other systems discussed here show ruffling of the porphyrin ring and lateral or vertical movements of the benzene cap, but no $\mathrm{M}-\mathrm{C}-\mathrm{O}$ angles $<172^{\circ}(\mathrm{M}=\mathrm{Fe}$ or
$\mathrm{Ru}$ ), despite the intense steric constraints engendered by some of these systems. It therefore seems unlikely to us that the $\mathrm{Fe}-\mathrm{C}-\mathrm{O}$ bending reported in $\mathrm{Mb}$ to be a major form of distortion upon $\mathrm{CO}$ ligation is real. The precision with which $\mathrm{Fe}-\mathrm{C}-\mathrm{O}$ angles are known in these protein structures has been greatly overestimated $[16,17]$, and so the entire issue of significantly non-linear $\mathrm{Fe}-\mathrm{C}-\mathrm{O}$ bonds in hemoproteins may be moot. Although a recent calculation [55] suggests that the energy required to distort the $\mathrm{Fe}-\mathrm{C}-\mathrm{O}$ linkage is small, the structural results discussed here suggest that in the model systems steric effects are manifested in distortions of the porphyrin core rather than in the $\mathrm{Fe}-\mathrm{C}-\mathrm{O}$ linkage. Unfortunately, the precision of structure determinations of the proteins precludes an analysis of the fine details of porphyrin ruffling or doming, where it thus appears more likely that steric effects will be seen. Whether such steric effects play a significant role in the destabilization of $\mathrm{CO}$ binding or whether discrimination results primarily from stabilization of $\mathrm{O}_{2}$ binding through hydrogen bonding remains an open question.

Acknowledgment This research was supported by the US National Institutes of Health [Grant HL13157 (J.A.I.)]. 


\section{References}

1. Antonini E, Brunori M (1971) Hemoglobin and myoglobin in their reactions with Ligands. North Holland, Amsterdam

2. Collman JP, Brauman JI, Halbert TR, Suslick KS (1976) Proc Natl Acad Sci USA 73:3333-3337

3. Heidner EJ, Ladner RC, Perutz MF (1976) J Mol Biol 104:707-722

4. Derewenda Z, Dodson G, Emsley P, Harris D, Nagai K, Perutz M, Reynaud J-P (1990) J Mol Biol 211:515-519

5. Jameson GB, Ibers JA (1994) In: Bertini I, Gray HB, Lippard SJ, Valentine JS (eds) Bioinorganic chemistry. University Science Books, Mill Valley, CA, pp 167-252

6. Springer BA, Sligar SG, Olson JS, Phillips J, George N (1994) Chem Rev 94:699-714

7. Jameson GB, Ibers JA (1983) Comments Inorg Chem 2:97126

8. Phillips SEV, Schoenborn BP (1981) Nature (London) 292:81-82

9. Jameson GB, Rodley GA, Robinson WT, Gagne RR, Reed CA, Collman JP (1978) Inorg Chem 17:850-857

10. Peng S-M, Ibers JA (1976) J Am Chem Soc 98:8032-8036

11. Hirota S, Li T, Phillips J George N, Olson JS, Mukai M, Kitagawa T (1996) J Am Chem Soc 118:7845-7846

12. Cheng X, Schoenborn BP (1991) J Mol Biol 220:381-399

13. Kuriyan J, Wilz S, Karplus M, Petsko GA (1986) J Mol Biol 192:133-154

14. Quillin ML, Arduini RM, Olson JS, Phillips GN Jr (1993) J Mol Biol 234:140-155

15. Yang F, Phillips GNJ (1996) J Mol Biol 256:762-774

16. Ray GB, Li X-Y, Ibers JA, Sessler JL, Spiro TG (1994) J Am Chem Soc 116:162-176

17. Guss JM, Bartunik HD, Freeman HC (1992) Acta Crystallogr, Sect B: Struct Sci 48:790-811

18. Chang CK, Traylor TG (1973) Proc Natl Acad Sci USA $70: 2647-2650$

19. Chang CK, Traylor TG (1973) J Am Chem Soc 95:58105811

20. Baldwin JE, Crossley MJ, Klose T, O'Rear EA III, Peters MK (1982) Tetrahedron 38:27-39

21. David S, James BR, Dolphin D, Traylor TG, Lopez MA (1994) J Am Chem Soc 116:6-14

22. Diekmann H, Chang CK, Traylor TG (1971) J Am Chem Soc 93:4068-4070

23. Traylor TG, Mitchell MJ, Tsuchiya S, Campbell DH, Stynes DV, Koga N (1981) J Am Chem Soc 103:5234-5236

24. David S, Dolphin D, James BR, Paine JB III, Wijesekera TP, Einstein FWB, Jones T (1986) Can J Chem 64:208-212

25. Ricard L, Fischer J, Weiss R, Momenteau M (1984) Nouv J Chem 8:639-642

26. Traylor TG, Tsuchiya S, Campbell D, Mitchell M, Stynes D, Koga N (1985) J Am Chem Soc 107:604-614

27. Collman JP, Zhang X, Wong K, Brauman JI (1994) J Am Chem Soc 116:6245-6251

28. Wuenschell GE, Tetreau C, Lavalette D, Reed CA (1992) J Am Chem Soc 114:3346-3355

29. Collman JP, Gagne RR, Reed CA, Halbert TR, Lang G, Robinson WT (1975) J Am Chem Soc 97:1427-1439

30. Collman JP, Brauman JI, Iverson BL, Sessler JL, Morris RM, Gibson QH (1983) J Am Chem Soc 105:3052-3064

31. Collman JP, Brauman JI, Collins TJ, Iverson BL, Lang G, Pettman RB, Sessler JL, Walters MA (1983) J Am Chem Soc 105:3038-3052

32. Collman JP, Brauman JI, Collins TJ, Iverson B, Sessler JL (1981) J Am Chem Soc 103:2450-2452
33. Almog J, Baldwin JE, Crossley MJ, Debernardis JF, Dyer RL, Huff JR, Peters MK (1981) Tetrahedron 37:3589-3601

34. Budge JR, Ellis PE Jr, Jones RD, Linard JE, Szymanski T, Basolo F, Baldwin JE, Dyer RL (1979) J Am Chem Soc $101: 4762-4763$

35. Shimizu M, Basolo F, Vallejo MN, Baldwin JE (1984) Inorg Chim Acta 91:247-250

36. Garcia B, Lee C-H, Blaskó A, Bruice TC (1991) J Am Chem Soc 113:8118-8126

37. Zhang H-Y, Blaskó A, Yu J-Q, Bruice TC (1992) J Am Chem Soc 114:6621-6630

38. Johnson MR, Seok WK, Ibers JA (1991) J Am Chem Soc 113:3998-4000

39. Tang H, Dolphin D (1996) Inorg Chem 35:6539-6545

40. Collman JP, Zhang X, Herrmann PC, Uffelman ES, Boitrel B, Straumanis A, Brauman JI (1994) J Am Chem Soc 116:2681-2682

41. Baldwin JE, Cameron JH, Crossley MJ, Dagley IJ, Hall SR, Klose T (1984) J Chem Soc, Dalton Trans 1739-1746

42. Ricard L, Weiss R, Momenteau M (1986) J Chem Soc, Chem Commun 818-820

43. Tetreau C, Lavalette D, Momenteau M, Fischer J, Weiss R (1994) J Am Chem Soc 116:11840-11848

44. Momenteau M, Reed CA (1994) Chem Rev 94:659-698

45. Traylor TG, Campbell D, Tsuchiya S, Mitchell M, Stynes DV (1980) J Am Chem Soc 102:5939-5941

46. Slebodnick C, Fettinger JC, Peterson HB, Ibers JA (1996) J Am Chem Soc 118:3216-3224

47. Kim K, Ibers JA (1991) J Am Chem Soc 113:6077-6081

48. Jameson GB, Ibers JA (1980) J Am Chem Soc 102:28232831

49. Slebodnick C, Duval ML, Ibers JA (1996) Inorg Chem $35: 3607-3613$

50. Slebodnick C, Kim K, Ibers JA (1993) Inorg Chem 32:53385342

51. Slebodnick C, Seok WK, Kim K, Ibers JA (1996) Inorg Chim Acta 243:57-65

52. Kim K, Fettinger J, Sessler JL, Cyr M, Hugdahl J, Collman JP, Ibers JA (1989) J Am Chem Soc 111:403-405

53. Johnson MR, Seok WK, Ma W, Slebodnick C, Wilcoxen KM, Ibers JA (1996) J Org Chem 61:3298-3303

54. Bag N, Grogan TM, Magde D, Slebodnick C, Johnson MR, Ibers JA (1994) J Am Chem Soc 116:11833-11839

55. Ghosh A, Bocian DF (1996) J Phys Chem 100:6363-6367

56. Romero-Herrera AE, Goodman M, Dene H, Bartnicki DE, Mizukami H (1981) J Mol Evol 17:140-147

57. Gibson QH (1970) J Biol Chem 245:3285-3288

58. Olson JS, Anderson ME, Gibson QH (1971) J Biol Chem 246:5919-5923

59. Sharma VS, Schmidt MR, Ranney HM (1976) J Biol Chem 251:4267-4272

60. Steinmeier RC, Parkhurst LJ (1975) Biochemistry 14:15641572

61. Linard JE, Ellis PE Jr, Budge JR, Jones RD, Basolo F (1980) J Am Chem Soc 102:1896-1904

62. Hashimoto T, Dyer RL, Crossley MJ, Baldwin JE, Basolo F (1982) J Am Chem Soc 104:2101-2109

63. Sawicki CA, Gibson QH (1977) J Biol Chem 252:7538-7547

64. Green MLH, Moreau JJE (1978) Inorg Chim Acta 31:L461L462

65. Sabat M, Ibers JA (1982) J Am Chem Soc 104:3715-3721

66. Sparapany JW, Crossley MJ, Baldwin JE, Ibers JA (1988) J Am Chem Soc 110:4559-4564 